\author{
Paulina ANIOLA-MIKOLAJCZAK, PhD \\ Faculty of Economics and Social Sciences, Poznan University of Life Sciences \\ email: aniola@up.poznan.pl
}

DOI: $10.15290 /$ ose.2016.05.83.09

\title{
A CLASSIFICATION OF POLISH HOUSEHOLDS BASED ON A CREDIT PORTFOLIO AND DEBT SERVICE RATIO ${ }^{1}$
}

\begin{abstract}
Summary
The aim of this paper is to show the diversity of Polish households' financial behavior in terms of debt as well as an identification of households that are characterized by a high debt to income ratio. The article also attempt to assess the debt to income ratio as a measure of households over-indebtedness. To achieve the main objective, the cluster analysis method was used. Based on the households credits portfolio and the level of debt to income ratio, 11 homogeneous groups of households were generated. Five of them were characterized by a high debt to income ratio $(>30 \%)$, which classify them as overindebted.
\end{abstract}

Key words: over-indebtedness, Polish households, debt to income ratio, credit portfolio, cluster analysis

JEL: D10, D14

\section{Introduction}

The increase of households debt level is characteristic of most developed economies [Bloxham, Kent, 2009]. Moreover, in the theory of economics the debt is perceived as an instrument stabilizing the level of household consumption in time [Gumy, 2007; Barba, Pivetti, 2009; Świecka, 2009], which is directly related to the life-cycle hypothesis [Modigliani, Brumberg, 1954]. In the early stages of the life cycle of a household, when the demand for funds is high and the level of savings is small, a credit plays an important role. Therefore, saving and borrowing of households are mechanisms for smoothing consumption in time. Households use credits when their incomes are low and save when their income increases [Świecka, 2009; Vandone, 2009; Betti et al., 2001].

However, the dynamic increase in the volume and value of loans provided to households, together with financial mismanagement and a lack of financial awareness, due

\footnotetext{
${ }^{1}$ The project was financed from the resources of The National Science Centre based on the decision number DEC-2012/05/N/HS4/00227
} 
in large part to the scarcity of financial education, can contribute to over-indebtedness [Bywalec, 2009; Świecka, 2008, 2009]. It is therefore necessary to distinguish two types of terms: indebtedness and over-indebtedness [Russell et al, 2011; Vandone, 2009; Gumy, 2007; Disney et al., 2008].

Overindebtedness is a relatively new term which, because of its complex and multidimensional nature has not yet been clearly interpreted [Vandone, 2009; Świecka, 2008, 2009; European Commission, 2008; Keese, 2009; Kempson, 2002; Schicks, 2010; Bricks, McKee, 2010; Carprntier, van den Bosch, 2008; Bryan et al., 2010; Russell et al., 2011; D’Alessio, Iezzi, 2012; Bridges, Disney, 2004; Kempson et al., 2004; Betti et al., 2007; OXERA, 2004].

So far many different indicators of over-indebtedness was created. Household can be regarded as being at risk of over-indebtedness if a significant part of their income is spent on debt service. Therefore, one of the most often measures of over-indebtedness is debt service ratio. For gaining information on whether the debt servicing costs are not excessive, it is necessary to determine the threshold of this indicator. In the literature it is taken at the level 20-50\% Rebiere, 2007; Carpentier, Van den Bosch, 2008; DeVaney, 1994; DeVaney, Lytton, 1995; Faruqui, 2006; MORI 2003; OXERA, 2004; D’Alessio, Iezzi, 2012; Beer, Schürz, 2007; Kempson, 2002].

Another indicator used in the researches of over-indebtedness is margin ${ }^{2}$ [Zajączkowski, Żochowski, 2007; Johansson, Persson, 2006]. Margin is the amount that stays in a household after deducting current income by the amount allocated for debt repayment and other fixed expenditures. The negative margin may indicate financial problems of household. It means an inability of household to repay debt and basic expenses from a current income.

Other indicators measuring over-indebtedness are based on arrears [D'Alessio, Iezzi, 2012; Carpentier, van den Bosch, 2008; Bryan et al., 2010; Disney et al., 2008], the number of credit commitments [D'Alessio and Iezzi 2012 Bryan et al., 2010 Disney et al. 2008] or a subjective assessment of the financial situation of household [D'Alessio, Iezzi, 2012; Carpentier, van den Bosch, 2008; Bryan et al., 2010; Disney et al., 2008].

The aim of this paper is to show the diversity of Polish households' financial behavior in terms of debt as well as an identification of households that are characterized by a high debt to income ratio. The article also attempt to assess the debt to income ratio as a measure of households over-indebtedness.

\section{Data and methods}

The study was based on data from Household Budget Survey in 2011, which was conducted by Central Statistical Office of Poland. The study involved 37375 households, of which $30 \%$ were indebted. Analysis was performed on indebted households with the use of cluster analysis.

\footnotetext{
${ }^{2}$ Margin was determined by basic types of expenditure method - household income is reduced by the amount of real incurred fixed expenditures such as rent, energy and by expenditures on basic goods and services such as food, transport, housing, water.
} 
The cluster analysis, non-hierarchical, k-means method was used to study the composition of households' debt portfolio. Due to the size of research sample and qualitative dependent variable data-mining module was used. The basic criterion for the classification using cluster analysis were different financial products, as well as the level of debt service ratio. Cluster analysis was conducted on the basis of 5 variables representing different forms of debt (mortgage, debt in credit card, credit in bank, credit in other institutions and loans from private persons) as well as debt to income ratio. If the level of this indicator is bigger than $30 \%$, then a household is perceived as over-indebted. The fact of declaring (yes-no) by a household the listed above forms of debt and the level of debt to income ratio (yes=the level of indicator is bigger than $30 \%$ ) was a basis for identification and naming the types of households (Table 1).

The obtained results were the basis for profiling clusters (types of households). The profiling was conducted by cross-tabulation using contingency tables, which show the simultaneous distribution of several features.

\section{Results}

Conducted cluster analysis based on the structure of households credit portfolio and the level of debt to income ratio allowed to distinguish and identify 11 homogeneous groups of households. Five of them, clusters 1, 3, 6, 8 and 9, were characterized by a high level of debt-to-income (over 30\%), which classifies them as over-indebted in the light of debt service ratio (Table 2). Distinguished clusters were characterizes by following features:

Cluster 1 - the least numerous and most diverse in terms of structure of credit portfolio. It is formed by only 103 households, this is less than $1 \%$ of analyzed population. The mortgages dominated in a credit portfolio of this group of households (19\% of disposable income). Also bank credits ( $6 \%$ of disposable income) and credits in other institutions ( $9 \%$ of disposable income) were popular in these households. Debt service ratio, compared to other groups with a high debt to income ratio, was relatively small and amounted 38\%. Margin in this cluster amounted as much as PLN 1925 and was the highest among households where debt to income ratio exceeded 30\%. Relatively low was in this group the percentage of households with insufficient income to cover debt repayment and basic expenses related with functioning of household (15.5\%). The high level of margin and a low percentage of households with a negative margin was affected by very high income received by the representatives of this cluster. Average equivalent income in the group amounted more than PLN 2,880 and thus was the highest among all distinguished clusters. In addition, it is worth emphasizing that as many as $64 \%$ of households of this cluster receives the highest income (fifth quintile).

Households from the first cluster were characterized by the following socio-economic features:

- $\quad$ relatively low age of the head of household $(65 \%$ of households were run by people aged 25-44),

- relatively high percentage of households with dependent children, 
- $\quad$ dominance of households run by staff of private or public sector (almost 90\%),

- $\quad$ relatively high proportion of households (30\%) of small towns (from 20-99 thousand inhabitants),

- $\quad$ a high level of education of householders (more than half (53\%) of households led by people with higher education).

TABLE 1.

Indicators of cluster analysis - having (YES) or not having (NO) particular kinds of credits and debt to income ratio $>30 \%$

\begin{tabular}{|l|c|c|c|c|c|c|c|c|c|c|c|}
\hline \multirow{2}{*}{ Indicators } & \multicolumn{10}{|c|}{ Clusters } \\
\cline { 2 - 13 } & $\mathbf{1}$ & $\mathbf{2}$ & $\mathbf{3}$ & $\mathbf{4}$ & $\mathbf{5}$ & $\mathbf{6}$ & $\mathbf{7}$ & $\mathbf{8}$ & $\mathbf{9}$ & $\mathbf{1 0}$ & $\mathbf{1 1}$ \\
\hline Mortgage & yes & no & no & yes & yes & yes & no & yes & no & no & no \\
\hline $\begin{array}{l}\text { Debt in credit } \\
\text { card }\end{array}$ & no & no & no & no & no & no & yes & no & no & no & no \\
\hline Credit in bank & yes & yes & yes & yes & no & no & no & yes & yes & no & no \\
\hline $\begin{array}{l}\text { Credit in other } \\
\text { institutions }\end{array}$ & yes & no & no & no & no & no & no & no & yes & yes & no \\
\hline $\begin{array}{l}\text { Loans from } \\
\text { private persons }\end{array}$ & no & no & no & no & no & no & no & no & no & no & yes \\
\hline $\begin{array}{l}\text { Debt to income } \\
\text { ratio }>30 \%\end{array}$ & yes & no & yes & no & no & yes & no & yes & yes & no & no \\
\hline $\begin{array}{l}\text { Numer of } \\
\text { households }\end{array}$ & 103 & 6391 & 648 & 378 & 1464 & 305 & 452 & 236 & 161 & 749 & 164 \\
\hline $\begin{array}{l}\% \text { of } \\
\text { households }\end{array}$ & 0.9 & 57.8 & 5.9 & 3.4 & 13.2 & 2.8 & 4.1 & 2.1 & 1.5 & 6.8 & 1.5 \\
\hline
\end{tabular}

Source: The authors' own compilation based on Household Budget Survey in 2011.

Cluster 3 - the largest in terms of number, among clusters where the value of household debt exceeds $30 \%$ of their income. It counts 648 households, which is nearly $6 \%$ of the analyzed population. This cluster is characterized by the highest debt to income ratio $(63 \%)$. Households representing this cluster were indebted mainly in banks and this kind of credit absorbed almost $60 \%$ of their income. Little significance in this group had: debt in credit card (3\% of income) and loans from private persons ( $2.4 \%$ of incomes). Households in this cluster were characterized by relatively low equivalent income (PLN 1548). As much as every fourth household in this group received equivalent income at a level of the first quintile, and almost one in five (18.4\%) at the second quintile. Low incomes and high debt-to-income ratio translated in this cluster into the highest percentage of households with negative margin $(37 \%)$. The average value of margin in a whole cluster, was the lowest among all distinguished groups of households and it amounted only PLN 221.

Households from the third cluster were characterized by the following socioeconomic features:

- $\quad$ a relatively high percentage of single-person households $(22 \%)$,

- a relatively high percentage of retirees and pensioners households (41\%) and farmer households $(9 \%)$, 
- the dominance of households from rural areas (50\%),

- a high age of the head of household (average 51 years), almost half of the households in this cluster were run by persons over 55, and every fifth household - by a person over 65 ,

- $\quad$ low education of the head of household, half of the households were run by persons with at least primary education $(16 \%)$ and vocational/middle school education $(35 \%)$.

Cluster 6 was represented by 305 households (2.8\%), where debt level exceeded $30 \%$ of their incomes. The credit portfolio of households in this cluster was dominated by mortgages, which determined almost $60 \%$ incomes. On the other hand, little significance had debt in credit cards (3.8\% of income). The ratio of debt to income in households from this cluster, similar to cluster 3 , was very high and amounted as much as $63 \%$. However, in contrast to the households from cluster 3, households from this group were characterized by very high level of income. In this group of households The average equivalent income amounted to PLN 625. More than half of households from cluster $6(56 \%)$ received the highest income (quintile V), what translated into a higher level of margin (PLN 984) and a lower percentage of households with a negative margin $(18 \%)$.

Households from the sixth cluster were characterized by the following socio-economic features:

- $\quad$ a relatively high percentage of single-person households $(22 \%)$,

- a relatively high percentage of self employed $(21 \%)$,

- a relatively high percentage of households with one $(24 \%)$ or two $(19 \%)$ dependent children,

- relatively high percentage of households (50\%) living in big cities (with population over 500 thousand inhabitants),

- $\quad$ low age of head of the household (average 38 years old), as much as $3 / 4$ of households are run by persons below 44 years old),

- $\quad$ high level of education of head of the household.

Cluster 8 was formed by 236 households (2.1\%), where the average level of debt to income ratio amounted $44 \%$. In a credit portfolio dominated mortgages $(25 \%$ of income) and credits in banks (16\% of income). Households from this cluster are characterized by quite high equivalent income (average PLN 2333). Half of the household from this cluster had the highest level of income (quintile V).

Moreover, household from cluster 8 , generally well coped with debt repayment and covering basic expenses. Only 15\% of households had a negative margin. Although, considering relatively high income, the level of margin was in these households not high and amounted about PLN 1000. 
TABLE 2.

Synthetic characteristics of households with high debt to income ratio $(>30 \%)$

\begin{tabular}{|c|c|c|c|c|c|}
\hline \multirow[t]{2}{*}{ Features } & \multicolumn{5}{|c|}{ Clusters } \\
\hline & 1 & 3 & 6 & 8 & 9 \\
\hline $\begin{array}{l}\text { Dominant } \\
\text { type of } \\
\text { credit } \\
\text { ( } \% \text { of } \\
\text { income) }\end{array}$ & $\begin{array}{c}\text { mortgage } \\
(19 \%) \\
\text { in banks }(6 \%) \\
\text { in other } \\
\text { institutions } \\
(9 \%)\end{array}$ & $\begin{array}{c}\text { in banks } \\
(57 \%)\end{array}$ & $\begin{array}{c}\text { mortgage } \\
(59 \%)\end{array}$ & $\begin{array}{c}\text { mortgage }(25 \%) \\
\text { in banks }(16 \%)\end{array}$ & $\begin{array}{c}\text { in banks } \\
(17 \%) \\
\text { in other } \\
\text { institutions } \\
(28 \%)\end{array}$ \\
\hline $\begin{array}{c}\text { Debt to } \\
\text { income ratio }\end{array}$ & $38 \%$ & $63 \%$ & $63 \%$ & $44 \%$ & $49 \%$ \\
\hline margin & PLN 1925 & PLN 221 & PLN 984 & PLN 1056 & PLN 321 \\
\hline $\begin{array}{c}\% \text { of } \\
\text { households } \\
\text { with negative } \\
\text { margin }\end{array}$ & $16 \%$ & $37 \%$ & $18 \%$ & $15 \%$ & $32 \%$ \\
\hline $\begin{array}{c}\text { Age of } \\
\text { a head of } \\
\text { household }\end{array}$ & low & high & low & low & high \\
\hline $\begin{array}{c}\text { Equivalent } \\
\text { income }\end{array}$ & $\begin{array}{l}\text { very high } \\
\text { (PLN 2884) }\end{array}$ & $\begin{array}{c}\text { low } \\
\text { (PLN 1548) } \\
\end{array}$ & $\begin{array}{c}\text { very high } \\
\text { (PLN 2626) }\end{array}$ & $\begin{array}{l}\text { quite high } \\
\text { (PLN 2333) }\end{array}$ & $\begin{array}{c}\text { average } \\
\text { (PLN 1720) }\end{array}$ \\
\hline $\begin{array}{l}\text { Biological } \\
\text { type of } \\
\text { family }\end{array}$ & $\begin{array}{l}\text { households } \\
\text { with } \\
\text { dependent } \\
\text { children }\end{array}$ & $\begin{array}{c}\text { single- } \\
\text { person } \\
\text { households }\end{array}$ & $\begin{array}{l}\text { single-person } \\
\text { households, } \\
\text { couples with } \\
\text { one or two } \\
\text { dependent } \\
\text { children }\end{array}$ & $\begin{array}{c}\text { couples with one } \\
\text { or two } \\
\text { dependent } \\
\text { children }\end{array}$ & $\begin{array}{c}\text { single-person } \\
\text { households }\end{array}$ \\
\hline $\begin{array}{l}\text { Socio- } \\
\text { economic } \\
\text { group }\end{array}$ & $\begin{array}{c}\text { staff of } \\
\text { private or } \\
\text { public sector }\end{array}$ & $\begin{array}{c}\text { retirees and } \\
\text { pensioners, } \\
\text { farmers }\end{array}$ & self employed & $\begin{array}{l}\text { staff of private } \\
\text { or public sector }\end{array}$ & $\begin{array}{l}\text { retirees and } \\
\text { pensioners }\end{array}$ \\
\hline $\begin{array}{l}\text { Type of } \\
\text { place }\end{array}$ & $\begin{array}{c}\text { small cities with } \\
\text { population } \\
20-99 \\
\text { thousand } \\
\text { inhabitants }\end{array}$ & village & $\begin{array}{c}\text { very big cities } \\
\text { with population } \\
\text { over } 500 \\
\text { thousand } \\
\text { inhabitants }\end{array}$ & - & village \\
\hline $\begin{array}{l}\text { Education } \\
\text { of a head of } \\
\text { household }\end{array}$ & high & low & high & quite high & low \\
\hline $\begin{array}{c}\text { Sex of } \\
\text { a head of } \\
\text { household }\end{array}$ & - & - & - & man & - \\
\hline
\end{tabular}

Source: The authors' own compilation based on Household Budget Survey in 2011. 
Households from the eighth cluster were characterized by the following socioeconomic features:

- $\quad$ low age of the head of household (average 40 years old), $70 \%$ of households were run by people below 44 years old,

- a relatively high percentage of households with one $(25 \%)$ or two $(25 \%)$ dependent children,

- dominance of households run by staff of private or public sector (75\%),

- $\quad$ quite high level of education of a head of household. More than $40 \%$ of households were run by persons with higher education (40\%), and almost $40 \%$ households were run by persons with secondary education,

- relatively high percentage of households run by men $(72 \%)$.

Cluster 9 consist of only 161 households (1.5\% of analyzed population). The debt to income ratio in this group of households amounted $49 \%$. In a debt structure dominated credits from other institutions (28\% of income) and credits in banks (17\% of income). Little significance had debt in credit cards (3.5\% of incomes) and loans from private persons (1\% of income). Households classified to cluster 9, were characterized by average level of equivalent income (PLN 1720), very low margin (PLN 320) and high percentage of households with negative margin (32\%).

Households from the ninth cluster were characterized by the following socioeconomic features:

- the highest among all distinguished clusters age of the head of household (average 52 years old), $75 \%$ of household be run by people over 45 years old,

- a relatively high percentage of single-person households (17\%),

- a relatively high percentage of retirees and pensioners households $(28 \%)$,

- $\quad$ almost half of the households were located on village (44\%),

- low level of education of a head of household, relatively high proportion of households run by persons with primary school and lower education (15\%) and vocational or middle school education $(32 \%)$.

The other six distinguished groups of households (clusters: 2, 4, 5, 7, 10, 11) were characterized by a low debt to income ratio, not exceeding 30\% (table 3). Therefore in the light of the criterion of debt-to-income indicator, these are households without problem of over-indebtedness. 
TABLE 3.

Synthetic characteristics of households with low debt to income ratio $(<30 \%)$

\begin{tabular}{|c|c|c|c|c|c|c|}
\hline \multirow[t]{2}{*}{ Feature } & \multicolumn{6}{|c|}{ Clusters } \\
\hline & 2 & 4 & 5 & 7 & 10 & 11 \\
\hline $\begin{array}{c}\text { Dominant } \\
\text { type of } \\
\text { credit } \\
\text { ( } \% \text { of } \\
\text { income) }\end{array}$ & $\begin{array}{c}\text { in banks } \\
(11 \%)\end{array}$ & $\begin{array}{c}\text { mortgage } \\
(12 \%) \\
\text { in banks } \\
(6 \%)\end{array}$ & $\begin{array}{c}\text { mortgage } \\
(15 \%)\end{array}$ & $\begin{array}{c}\text { credit card } \\
(16 \%)\end{array}$ & $\begin{array}{c}\text { in other } \\
\text { institutions } \\
(10 \%)\end{array}$ & $\begin{array}{c}\text { from private } \\
\text { persons } \\
(16 \%)\end{array}$ \\
\hline $\begin{array}{l}\text { Debt to } \\
\text { income } \\
\text { ratio }\end{array}$ & $11 \%$ & $19 \%$ & $16 \%$ & $17 \%$ & $10 \%$ & $16 \%$ \\
\hline margin & PLN 1533 & PLN 3107 & PLN 3141 & PLN 1792 & PLN 1956 & PLN 612 \\
\hline $\begin{array}{c}\% \% \text { of } \\
\text { households } \\
\text { with negative } \\
\text { margin }\end{array}$ & $7 \%$ & $0.5 \%$ & $2 \%$ & $11 \%$ & $6 \%$ & $19 \%$ \\
\hline $\begin{array}{c}\text { Age of } \\
\text { a head of } \\
\text { household }\end{array}$ & high & low & low & average & average & $\begin{array}{l}\text { large age } \\
\text { span }\end{array}$ \\
\hline $\begin{array}{l}\text { Equivalent } \\
\text { income }\end{array}$ & $\begin{array}{l}\text { average } \\
\text { (PLN } \\
1620)\end{array}$ & $\begin{array}{l}\text { the } \\
\text { highest } \\
\text { (PLN } \\
2734 \text { ) }\end{array}$ & $\begin{array}{l}\text { very high } \\
\text { (PLN } \\
2730)\end{array}$ & $\begin{array}{c}\text { average } \\
\text { (PLN } \\
2115)\end{array}$ & $\begin{array}{c}\text { average } \\
\text { (PLN 1869) }\end{array}$ & $\begin{array}{c}\text { low } \\
\text { (PLN 1163) }\end{array}$ \\
\hline $\begin{array}{l}\text { Biological } \\
\text { type of } \\
\text { family }\end{array}$ & $\begin{array}{l}\text { couples } \\
\text { with } \\
\text { dependent } \\
\text { children } \\
\text { and others }\end{array}$ & $\begin{array}{c}\text { couples } \\
\text { with } \\
\text { dependent } \\
\text { children }\end{array}$ & $\begin{array}{c}\text { couples } \\
\text { with } \\
\text { dependent } \\
\text { children }\end{array}$ & $\begin{array}{c}\text { single- } \\
\text { person } \\
\text { household }\end{array}$ & $\begin{array}{l}\text { couples with } \\
\text { dependent } \\
\text { children and } \\
\text { others }\end{array}$ & $\begin{array}{l}\text { single-person } \\
\text { household, } \\
\text { single-parent } \\
\text { families }\end{array}$ \\
\hline $\begin{array}{l}\text { Socio- } \\
\text { economic } \\
\text { group }\end{array}$ & $\begin{array}{c}\text { retirees } \\
\text { and } \\
\text { pensioners }\end{array}$ & $\begin{array}{l}\text { staff of } \\
\text { private } \\
\text { or public } \\
\text { sector }\end{array}$ & $\begin{array}{c}\text { self } \\
\text { employed }\end{array}$ & $\begin{array}{c}\text { retirees } \\
\text { and } \\
\text { pensioners }\end{array}$ & - & $\begin{array}{l}\text { retirees and } \\
\text { pensioners, } \\
\text { living on } \\
\text { unearned } \\
\text { sources }\end{array}$ \\
\hline $\begin{array}{l}\text { Type of } \\
\text { place }\end{array}$ & village & - & $\begin{array}{l}\text { very big } \\
\text { cities with } \\
\text { population } \\
\text { over } 500 \\
\text { thousand } \\
\text { inhabitants }\end{array}$ & $\begin{array}{l}\text { big cities } \\
\text { with } \\
\text { population } \\
\text { over } 100 \\
\text { thousand } \\
\text { inhabitants }\end{array}$ & $\begin{array}{l}\text { small cities } \\
\text { with } \\
\text { population } \\
\text { up to do } 99 \\
\text { thousand } \\
\text { inhabitants }\end{array}$ & - \\
\hline $\begin{array}{l}\text { Education } \\
\text { of a head of } \\
\text { household }\end{array}$ & low & $\begin{array}{l}\text { quite } \\
\text { high }\end{array}$ & high & quite high & low & $\begin{array}{l}\text { very } \\
\text { low }\end{array}$ \\
\hline $\begin{array}{c}\text { Sex of a } \\
\text { head of } \\
\text { household }\end{array}$ & - & man & man & - & - & woman \\
\hline
\end{tabular}

Source: The authors' own compilation based on Household Budget Survey in 2011. 


\section{Summary and conclusions}

Conducted cluster analysis based on the structure of households credit portfolio and the level of debt to income ratio allowed to distinguish and identify 11 homogeneous groups of households. Five of them were characterized by a high level of debt-toincome (over 30\%), which classifies them as over-indebted in the light of debt service ratio. On the basis of the cluster analysis the following conclusions can be drawn:

- The high debt to income ratio (over 30\%) do not necessarily mean financial problems of households. In the group of households with the highest debtto-income ratio $(63 \%)$ the proportion of households with a negative margin was $18 \%$, which means that in about every fifth household income was not sufficient to cover the debt repayment and basic costs associated with functioning of household. In turn, in a group of households where the debt to income ratio was much lower $(49 \%)$, the percentage of households with a negative margin was almost twice as high (32\%). In contrast, in households with very low debt service ratio (19\%), almost one fifth had a negative margin.

- $\quad$ Problems with covering basic costs associated with functioning of household and debt repayment had mainly households run by poorly educated people with low or middle-income. In case of households with high incomes led by people well educated, high level of debt to income ratio did not lead to financial problems.

- Households with mortgages relatively rarely had negative margin. They are characterized by high or very high incomes and even high debt burden did not cause financial problems in these households. The high debt to income ratio, related with drawdown of the mortgage, does not generate financial problems, and it should be assumed that it appeared mainly due to the specific nature of this kind of credit. Mortgages are characterized with quite high amounts of repaid installments and thus in relation to other categories of credits, the debt to income ratio in case of mortgage credits is generally high.

Based on the conducted research it can be stated that high level of debt to income ratio do not always reflect the negative financial situation of household. A much better measure of over-indebtedness seems to be negative margin which indicates a real financial problems of household.

\section{References}

Barba A., Pivetti M., 2009, Rising Household Debt: Its Causes and Macroeconomic Implications. A Long-Period Analysis, "Cambridge Journal of Economics", 33/2009, 113-137.

Beer Ch., Schürz M., 2007, Characteristic of Household Debt in Austria. Does Household Debt Pose a Threat to Financial Stability?, "Monetary Policy and The Economy", Q2/07.

Betti G., Dourmashkin N., Rossi M.., Ping Yin Y., 2007, Consumer Over-indebtedness in the EU:Measurement and Characteristics, ,Journal of Economic Studies” v. 34(2), 136-156. 
Betti G., Dourmashkin N., Rossi M.C., Verma V., Ping Yin Y., 2001, Study of the Problem of Consumer Indebtedness: Statistical Aspects, Report for the Directorate-General for Health and Consumer Protection, ORC Macro, London.

Bloxham P., Kent Ch., 2009, Household Indebtedness, "Australian Economic Review", 42(3), 327-39.

Bricks L., McKee K., 2010, Consumer Protection Regulation in Low-Access Environments: Opportunities to Promote Responsible Finance, Focus Note no. 60, CGAP, Washington, DC.

Bridges S., Disney R., 2004, Use of Credit and Debt among Low-Income Families in the UK. An Empirical Analysis, "Fiscal Studies", vol. 25, 1-25.

Bryan M., Taylor M., Veliziotis M., 2010, Overindebtedness in Great Britain: an Analysis Using The Wealth and Assets Survey and Household Annual Debtors Survey, Report to the Department for Business, Innovation and Skills, Institute for Social and Economic Research, University of Essex.

Bywalec Cz., 2009, Ekonomika i finanse gospodarstw domonych, PWN, Warszawa.

Carpentier S., Van den Bosch K., 2008, Problematic Debts in Belgium: Indicators Based on Belgian SILC 2004 and Profile of the Population with (Problematic) Indebtedness, "Working Paper Social Security", No. 7.

D’Alessio G., Iezzi S., 2012, Household Over-Indebtedness. Definition and Measurement with Italian Data, Sixth IFC Conference on "Statistical Issues and Activities in a Changing Environment" BIS, Basel, 28-29 August 2012.

DeVaney S. A., 1994, The Usefulness of Financial Ratios as Predictors of Housebold Insolvency - Two Perspectives, "Financial Counselling and Planning", Vol. 5, 5-24.

DeVaney S. A., Lytton R. H., 1995, Household Insolvency: A Review of Household Debt Repayment, Delinquency, and Bankruptcy, "Financial Services Review", 4(2), 137-156.

Disney R., Bridges S., Gathergood J., 2008, Drivers of Over-Indebtedness, Report to the Department for Business, Enterprise and Regulatory Reform, CPE, The University of Nottingham.

European Commission, 2008, Towards a Common Operational European Definition of OverIndebtedness, Directorate-General for Employment, Social Affairs and Equal Opportunities Inclusion, Social Policy Aspects of Migration, Streamlining of Social Policies Unit. Faruqui U., 2006, Are there Significant Disparities in Debt Burden across Canadian Households? An Examination of the Distribution of the Debt Service Ratio Using Micro Data, "IFC Bulletin", No 26, Measuring the Financial Position of the Household Sector, Vol. 2. Gumy J., 2007, Explaining Overindebtedness in the European Union (Paper Prepared for the BHPS 2007 Conference Colchester, 5th-7th July 2007), United Kingdom.

Johansson M. W., Persson M., 2006, Swedish Housebolds' Indebtedness and Ability to Paya Household Level Study, "IFC Bulletin", No 26, Vol. 2.

Keese M., 2009, Triggers and Determinants of Severe Household Indebtedness in Germany, "SOEP Papers" 239, DIW Berlin, The German Socio-Economic Panel (SOEP).

Kempson E., 2002, Over-Indebtedness in Britain. A Report to the Department of Trade and Industry, Personal Finance Research Centre, University of Bristol, Bristol.

Kempson E., McKay S., Willitts M., 2004, Research Report No 211: Characteristics of Families in Debt and the Nature of Indebtedness, Personal Finance Research Centre. 
Modigliani F., Brumberg R., 1954, Utility Analysis and the Consumption Function: An Interpretation of the Cross-Section Data, [in]: Post-Keynesion Economics, K. Kurihara (ed.), Rutgers University Press, New Brunswick, NJ, 388-436.

MORI, 2003, Financial Over-Commitment Survey, Citizen's Advice, London.

OXERA, 2004, Are UK Households Over-Indebted?, Commissioned by the Association for Payment Clearing Services, British Bankers Association, Consumer Credit Association and the Finance and Leasing Association.

Rebiere N., 2007, Community Statistics on Income and Living Conditions (EU-SILC) and Over-Indebtedness: the Example of France, Meeting of the Working Group of SRCV users (French module of the EU-SILC), 10/23/2007, INSEE, Paris.

Russell H., Maître B., Donnelly N., 2011, Financial Exclusion and Over-Indebtedness in Irish Households, Social Inclusion Research Report.

Schicks J., 2010, Microfinance Over-Indebtedness: Understanding its Drivers and Challenging the Common Myths, "CEB Working Paper", No. 10/048, Brussel.

Świecka B., 2008, Bankructwa gospodarstw domowych. Perspektywa ekonomiczna i społeczna, Difin, Warszawa.

Świecka B., 2009, Nienyptacalność gospodarstw domonych. Praycsyny - skutki-przecinwdziałanie, Difin, Warszawa.

Vandone D., 2009, Consumer Credit in Europe, Contributions to Economics, Springer, Berlin. Zajączkowski S., Żochowski D., 2007, Obciażenia gospodarsto domowych spłatami dtugu: rozklady $i$ stress testy - na podstawie badań budżetón gospodarstw domonych GUS, „Materiały i Studia", zeszyt nr 221, NBP, Warsaw. 